\title{
Nesting Biology of Lesser Canada Geese, Branta canadensis parvipes, along the Tanana River, Alaska
}

\author{
Craig R. Ely ${ }^{1}$, John M. Pearce ${ }^{1}$, and Roger W. Ruess ${ }^{2}$ \\ ${ }^{1}$ Alaska Science Center, U.S. Geological Survey, 4210 University Drive, Anchorage, Alaska 99508 USA \\ ${ }^{2}$ Institute of Arctic Biology, 211 Irving Building, University of Alaska, Fairbanks, Alaska 99775 USA
}
Ely, Craig R., John M. Pearce, and Roger W. Ruess. 2008. Nesting biology of Lesser Canada Geese, Branta canadensis parvipes, along the Tanana River, Alaska. Canadian Field-Naturalist 122(1): 29-33.

Lesser Canada Geese (Branta canadensis parvipes) are widespread throughout interior regions of Alaska and Canada, yet there have been no published studies documenting basic aspects of their nesting biology. We conducted a study to determine reproductive parameters of Lesser Canada Geese nesting along the Tanana River near the city of Fairbanks, in interior Alaska. Fieldwork was conducted in May of 2003, and consisted of locating nests along the riparian corridor between Fairbanks and Northpole, Alaska. Nests were found on gravel islands and shore habitats along the Tanana River, and were most commonly observed among driftwood logs associated with patches of alder (Alnus spp.) and willow (Salix spp.). Peak of nest initiation was 3-8 May, with a range from 27 April to 20 May; renesting was likely. Clutches ranged in size from 2 to 7 eggs and averaged 4.6 eggs. There was a negative correlation between clutch size and date of nest initiation. Egg size $(\bar{\chi}$ mass $=$ $128 \mathrm{~g}$ ) was similar to other medium-sized Canada Geese. A positive correlation between egg size and clutch size was likely related to female age. Nineteen of 28 nests $(68 \%)$ were active when visited; nests located on islands with nesting Mew Gulls (Larus canus) were more likely to be active than nests located elsewhere. Evidence at nest sites implicated Bald Eagles (Haliaeetus leucocephalus) and Red Foxes (Vulpes vulpes) as nest predators.

Key Words: Lesser Canada Goose, Branta canadensis parvipes, clutch, eggs, nesting ecology, Tanana River, Alaska.

Of the different subspecies of Canada Geese (Branta canadensis) that breed in Alaska and across northern Canada, the Lesser Canada Goose (B. c. parvipes) occupies the largest geographic area. Although the extent of the nesting distribution of Lesser Canada Geese is not completely known, their core breeding range is presumed to be interior Alaska, through Yukon Territory, northern British Columbia, northern Alberta, and western Northwest Territories [NWT] (Figure 1; Grieb 1970; Bellrose 1976; Johnson et al. 1979; Mowbray et al. 2002; Pearce and Bollinger 2003; Scribner et al. 2003). Lesser Canada Geese overlap with the breeding distribution of Taverner's Cackling Geese ( $B$. hutchinsii taverneri) in northern and western Alaska, and with Richardson's Cackling Geese (B. h. hutchinsii) across northern and eastern NWT and Nunavut (Dickson 2000; Hines et al. 2000; U. S. Fish and Wildlife Service 2003). Despite this wide breeding distribution, there have been no published investigations of the nesting ecology of Canada Geese in interior regions of northern Canada or Alaska (Bellrose 1976; Mowbray et al. 2002). Until this study, information on the reproductive attributes of $B$. c. parvipes has largely been inferred from studies in northern Canada of coastal-nesting B. h. hutchinsii (MacInnes 1962; MacInnes et al. 1974; Carriere et al. 1999). An increased understanding of the breeding biology of Canada Geese nesting in interior areas of Alaska and northwestern Canada will extend our appreciation of the diversity and adaptability of this ubiquitous goose and eventually lead to population management that can account for factors influencing reproductive performance.

\section{Study Area and Methods}

The study area was located in the Tanana River floodplain ecosystem, near Fairbanks, Alaska $\left(64^{\circ} 45^{\prime} \mathrm{N}\right.$ $147^{\circ} 27^{\prime} \mathrm{W}$ ), in the Fairbanks Northstar borough (Figure 1). Annual spring flooding scours the waterway and deposits driftwood on gravel bars and islands, braids stream channels, and maintains an early succession vegetation structure.

We visited the study area once in May 2003. Nests were located by travelling along the river by jet boat. Based on the number of geese and nests observed during initial searches, we focused subsequent search efforts within likely habitat areas using subjective criteria. A nest without feathers or eggs was not deemed active in the current nesting season unless the nest bowl was well developed and contained enough new nest material to cover an egg, as geese commonly make more than one scrape while selecting a suitable nest site but do not add grass to the bowl until an egg is laid (Mowbray et al. 2002). We determined the age of the eggs in the nest either by candling the eggs (Weller 1956) or by floating them to determine air cell volume (Westerskov 1950; Walter and Rusch 1997). When floating eggs, we identified 10 different float stages (four more divisions than Walter and Rusch 1997); estimates of nest age likely were accurate within $<3$ days (C. Ely, unpublished data on B. h. minima). Nest initiation dates were calculated by back-dating, assuming an incubation period of 26 days and one egg laid every 30 hours (Mowbray et al. 2002).

Egg volume $(\mathrm{mL})$ was determined using the equation $\mathrm{L} \times \mathrm{B} 2 \times \mathrm{K}$, where $\mathrm{K}$ is an egg-shape constant 


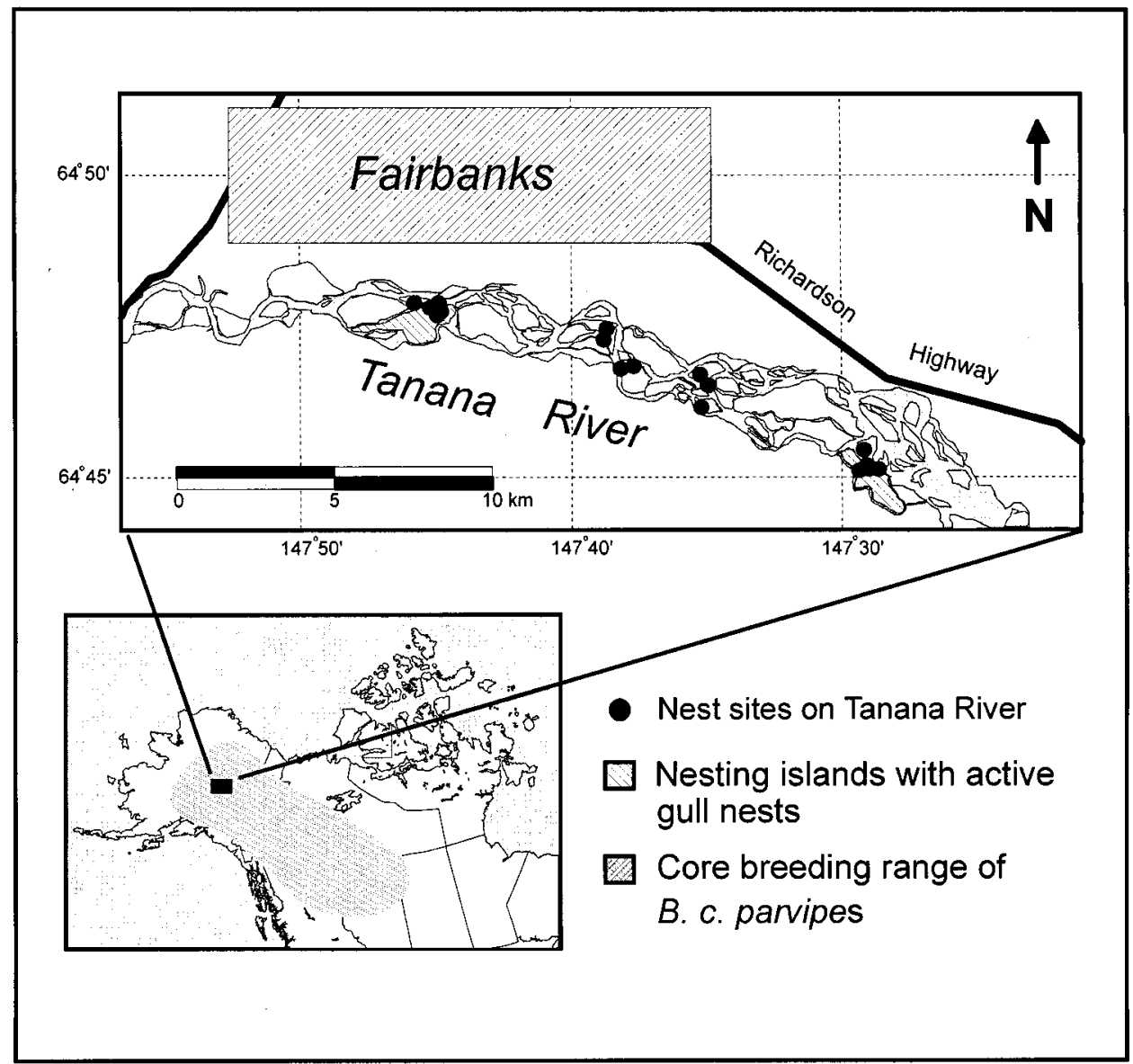

FiguRE 1. Location of Lesser Canada Goose study area on the Tanana River, Alaska, and breeding distribution of $B$. canadensis parvipes (after Grieb 1970; Bellrose 1976; Johnson et al. 1979; Mowbray et al. 2002).

determined to be 0.000556 for Canada Geese (Hoyt 1979; Mowbray et al. 2002). We tested for differences in nesting success between locations using a Fisher's Exact Test modification of a Chi-Square analysis (SAS Institute 1989). The relationship between clutch size and laying date was tested using regression analysis (SAS Institute 1989).

\section{Results and Discussion}

\section{Nest Initiation}

Timing of initiation of first nests varied from 27 April to 20 May, with a peak of 3-8 May (Figure 2). Timing of nesting in northern geese varies with habitat conditions (Raveling 1978). Habitat conditions during our study were likely similar to an average year. River ice broke on the Tanana River at Nenana, Alaska (about $80 \mathrm{~km}$ downstream from the study area) on 29 April in 2003, similar to the long-term average $(\overline{\mathrm{x}}=1$ May, range 21 April - 15 May; 1990 - 2002;
National Snow and Ice Data Center 2003). Our sample of nest initiation dates hence likely represents an average year. Extended periods of nest initiation are common in Cackling and Canada goose populations that frequently renest, and we suspect that nests initiated after 12 May were renests (see below).

\section{Nest Sites and Habitat}

Geese selected sites on large (>100 m) islands within the Tanana flood plain. Island substrates were largely composed of gravel, sand and small boulders, with little organic matter accumulation due to a high frequency of dynamic flooding. Vegetation on islands reflected soil types and was dominated by early succession alder (Alnus spp.), willow (Salix spp.), cottonwood and poplar (Populus spp.). Soils were welldrained and hence few graminoids were present. White Spruce (Picea glauca) was abundant on the perimeter of the flood plain. Goose nests were commonly 


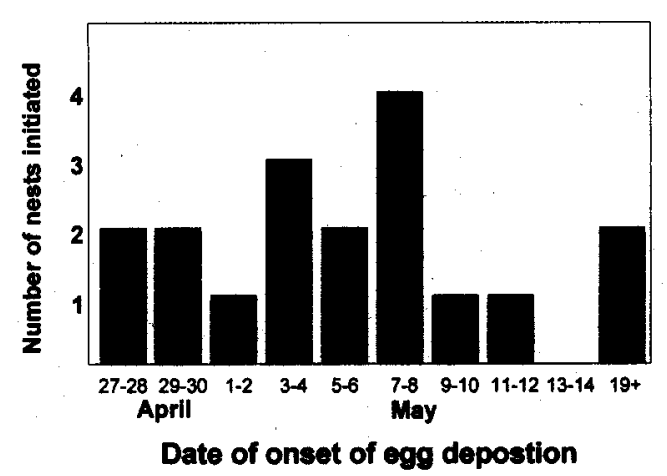

FIgURE 2. Timing of nest initiation of Lesser Canada Geese along the Tanana River, Alaska in 2003.

found among driftwood logs that had been deposited during high water on the Tanana River. A few islands of slightly higher elevation were dominated by large cottonwoods; on those islands organic soils supported a thick understory of vegetation, which often included wild rose (Rosa spp.) and various grasses and forbs. Nests on those islands were located on the perimeter of the island - presumably to improve predator detection.

Use of riverine habitats by nesting Canada Geese is common throughout their breeding range, and has been particularly noted for B. c. moffitti in the Pacific Northwest (Culbertson and Buss 1971; Reese et al. 1987). T. Barry (in Grieb 1970) reported that B. c. parvipes nesting in the Mackenzie drainage of Northwest Territories and northern Alberta used mostly streambanks, islands in rivers, and Beaver (Castor canadensis) ponds, and stated that they "definitely prefer faster moving water to nest by". In contrast, $B . h$. hutchinsii and $B$. h. taverneri generally nest on coastal flats or tundra habitat (Grieb 1970; Johnson et al. 1979). However, much needs to be learned about the distribution of the different subspecies of northernnesting Canada and Cackling geese before any variation in habitat preferences can be fully understood, as the breeding range of $B$. c. parvipes abuts (and overlaps with?) $B$. h. taverneri in the west and $B . h$. hutchinsii in northeastern Alaska, northern Yukon, Northwest Territories, and Nunavut (Mowbray et al. 2002).

\section{Clutch Size}

The mean clutch size was $4.58 \pm 0.33$ (SE) eggs (Figure 3). Clutches were slightly larger than reported for B. h. hutchinsii in Canada (4.3 eggs; MacInnes et al. 1974), and similar to clutch sizes of $B$. h. taverneri in Alaska (4.5 - 4.6 eggs on Colville River Alaska, 4.6 eggs on Yukon-Kuskokwim Delta, and 5.9 on the Seward Peninsula; Mowbray et al. 2002). Early nesting birds laid more eggs than birds nesting later, which led to a seasonal decline in clutch size $\left(\mathrm{F}_{1,16}=6.60\right.$, $P=0.02$; Figure 4). Such a phenomenon is common

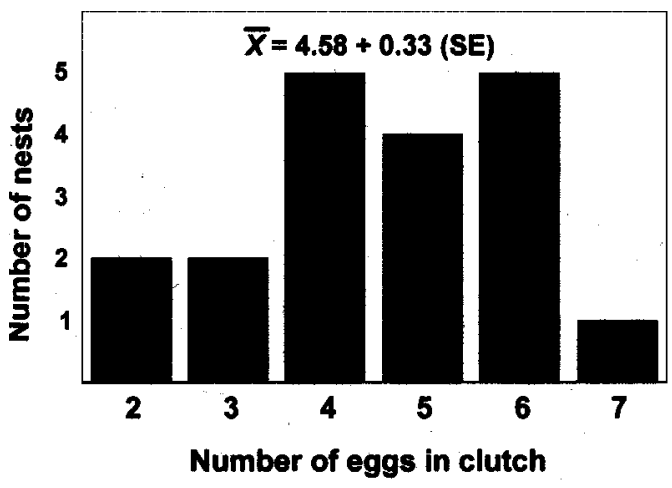

FIGURE 3. Distribution of clutch sizes of Lesser Canada Geese nesting along the Tanana River, Alaska in 2003.

in waterfowl and thought to be related to female age (older females generally nest earlier than inexperienced breeders; Aldrich and Raveling 1983) and the lesser energy reserves later-nesting females have available to devote to egg formation (Alisauskas and Ankney 1992).

\section{Egg Size}

Eggs had a mean length of $79.7 \pm 0.39 \mathrm{~mm}$ (SE) and a width of $53.74 \pm 0.17 \mathrm{~mm}$. Mean egg volume of $128.12 \mathrm{~mL}$ was similar to eggs of B. h. taverneri from the Yukon-Kuskokwim Delta $(121 \mathrm{~mL}$; B. McCaffery, personal communication; Mowbray et al. 2002), and the North Slope of Alaska (123 mL; Western Foundation of Vertebrate Zoology, unpublished data), and B. c. parvipes from Cook Inlet (125 mL; J. Hupp, unpublished data) and $B$. h. hutchinsii nesting in northern Nunavut (124 mL; MacInnes and Dunn 1988). Egg volume was positively correlated with clutch size ( $\mathrm{r}=0.425, P<0.0001 ; n=80$ eggs in 19 nests), as might be expected given that both egg size and clutch size increase with female age in Canada Geese (Mowbray et al. 2002).

\section{Nest Predation}

Nineteen of 28 nests $(68 \%)$ were active when visited. We visited nests only once, so estimates of nest success are only an index, and only indicative of true nesting success if: (1) active and inactive nests were equally likely to be detected, and (2) all nests active at the time of their discovery survived the remainder of the nesting period. It is unlikely that both these assumptions were met, so our estimates of nesting success are likely inflated. Evidence at destroyed nests implicated Bald Eagles (Haliaeetus leucocephalus) and Red Foxes (Vulpes vulpes) as nest predators; both are common predators of Canada Goose eggs in Alaska (Anthony et al. 2004). Additional predators that are common in the area and could cause nest loss included Wolves (Canis lupus), Coyotes (Canis latrans), Grizzly Bears (Ursus horribilis) and American Marten 
(Martes americana), as well as Glaucous Gulls (Larus hyperboreus). One island near a landfill supported an abundant Common Raven (Corvus corvus) population; it contained one nest that was inactive.

Nests located on islands with nesting Mew Gulls (Larus canus) were more likely to be active than nests located elsewhere. Sixteen of 17 (94\%) goose nests located on islands with gull colonies were active when discovered, compared to only 3 of $11(27 \%)$ active nests found at locations without nesting colonies of Mew Gulls $\left(\chi^{2}=13.68\right.$, df $\left.=1, P=0.0004\right)$. The apparent higher proportion of active nests on islands with gulls seems likely related to an absence of terrestrial predators rather than any nest protection gulls might offer geese nesting in the vicinity. Goose nests were not in close proximity to gull nests, and gulls did not harass observers away from their nests. A similar situation has been reported for island-nesting Redbreasted Geese (B. ruficollis) on the Taimyr Peninsula (Quinn et al. 2003).

Many goose nests were located among driftwood logs, and hence were situated at the elevation of the highest floods. Flood stage on the Tanana at Fairbanks is considered to be $7.5 \mathrm{~m}$ (National Oceanic and Atmospheric Administration 2003), and has been attained 4 times in the past decade (National Oceanic and Atmospheric Administration 2003). Flooding events usually occur in July and August due to heavy rainfall in the Tanana River Basin. As such, most flooding events occur after incubation has been completed, although occasional floods in late June could impact birds that renest or delay nest initiation.

\section{Distribution}

Band-return data indicate that Canada Geese from the Tanana River region and elsewhere in interior Alaska winter primarily in eastern Washington, eastern Oregon, and southern British Columbia (Mowbray et al. 2002; C. Ely, unpublished data). This distribution is distinct from Canada Geese nesting in the vicinity of Cook Inlet (400 km south of the Tanana; also assigned to B. c. parvipes - see Scribner et al. 2003), that winter mostly in western Oregon and Washington, and tundra-nesting $B$. h. hutchinsii and B. c. parvipes populations which breed from northeast Alaska through Yukon Territory, Northwest Territories, and Nunavut (Grieb 1970; Mowbray et al. 2002) that predominantly winter in the Central Flyway. However, affinities of waterfowl based on band return data alone can be difficult to interpret, and genetic studies are currently underway to better understand the distribution and breeding ranges of $B$. $c$. parvipes and $B$. h. taverneri in Alaska.

\section{Acknowledgments}

We thank M. Eicholz for directing us to locations where we would likely find goose nests, and to the early cartographer who appropriately named one of the islands in our study area "Goose Island". J. Hupp

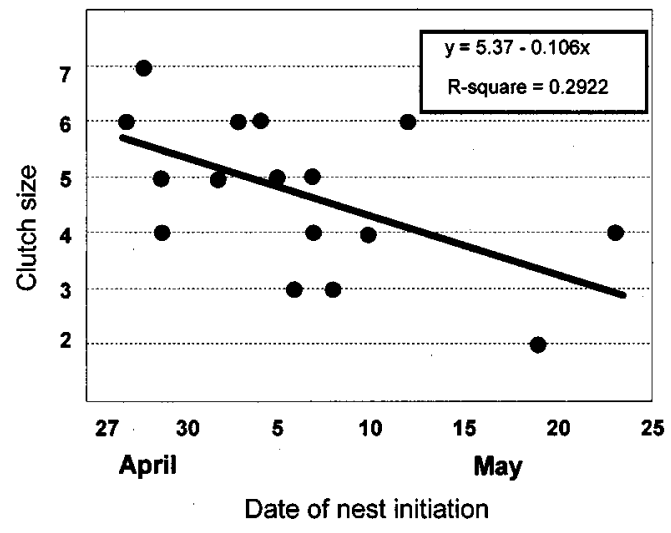

FIGURE 4. Seasonal decline in clutch size of Lesser Canada Geese nesting along the Tanana River, Alaska in 2003.

and J. Fischer kindly reviewed an earlier draft of this paper.

\section{Literature Cited}

Aldrich, T. W., and D. G. Raveling. 1983. Effects of experience and body weight on incubation behavior of Canada Geese. Auk 100: 670-679.

Alisausksas, R. T., and C. D. Ankney. 1992. The cost of egg laying and its relationship to nutrient reserves in waterfowl. Pages 30-61 in Ecology and management of breeding waterfowl. Edited by B. D. J. Batt, A. D. Afton, M. G. Anderson, C. D. Ankney, D. H. Johnson, J. A. Kadlec, and C. G. Krapu. University of Minnesota Press, Minneaopolis.

Anthony, R. M., J. B. Grand, T. F. Fondell, and B. F. Manly. 2004. A quantitative approach to identifying predators from nest remains. Journal of Field Ornithology 75: 40-48.

Bellrose, F. C. 1976. Ducks, geese and swans of North America. $2^{\text {nd }}$ Edition. Stackpole Books, Harrisburg, Pennsylvania. 544 pages.

Carriere, S., R. G. Bromley, and G. Gauthier. 1999. Comparative spring habitat and food use by two arctic nesting geese. Wilson Bulletin 111: 166-180.

Culbertson, J. L., and I. O. Buss. 1971. Nesting and movements of Canada Geese on the Snake River in Washington. Condor 73: 230-236.

Dickson, K. M. 2000. The diversity of Canada Geese. Pages 11-24 in Towards conservation of the diversity of Canada Geese (Branta canadensis). Edited by K. M. Dickson, Canadian Wildlife Service Occasional Papers (103).

Grieb, J. R. 1970. The shortgrass prairie Canada goose population. Wildlife Monographs 22. 49 pages.

Hines, J. E., D. L. Dickson, B. C. Turner, M. O. Wiebe, S. J. Barry, T. A. Barry, R. J. Kerbes, D. J. Nieman, M. F. Kay, M. A. Fournier, and R. C. Cotter. 2000. Population status, distribution, and survival of Shortgrass Prairie Canada Geese from the Inuvialuit Settlement Region, Western Canadian Arctic. Pages 27-58 in Towards conservation of the diversity of Canada Geese (Branta canadensis). Edited by K. M. Dickson. Canadian Wildlife Service Occasional Paper (103).

Hoyt, D. F. 1979. Practical methods of estimating volume and fresh weight of bird eggs. Auk 96: 73-77. 
Johnson, D. H., D. E. Timm, and P. F. Springer. 1979. Morphological characteristics of Canada Geese in the Pacific Flyway. Pages 56-80 in Management and biology of Pacific Flyway geese. Edited by R. L. Jarvis and J. C. Bartonek, Oregon State University Book Stores, Inc, Corvallis.

MacInnes, C. D. 1962. Nesting of small Canada Geese near Eskimo Point, Northwest Territories. Journal of Wildlife Management 26: 247-256.

MacInnes, C. D., R. A. Davis, R. N. Jones, B. C. Lieff, and A. J. Pakulak. 1974. Reproductive efficiency of McConnell River small Canada Geese. Journal of Wildlife Management 38: 686-707.

MacInnes, C. D., and E. H. Dunn. 1988. Components of clutch size variation in arctic-nesting Canada Geese. Condor 90: 83-89.

Mowbray, T. B., C. R. Ely, J. S. Sedinger, and R. E. Trost. 2002. Canada Goose (Branta canadensis). In The Birds of North America. (682) Edited by A. Poole and F. Gill. The Birds of North America, Inc., Philadelphia, Pennsylvania.

National Oceanic and Atmospheric Administration. 2003. Alaska Pacific River Forecast Center. Tanana River at Fairbanks. National Weather Service. Silver Spring, Maryland.

National Snow and Ice Data Center. 2003. Nenana Ice Classic: Tanana River Ice Annual Breakup Dates. National Snow and Ice Data Center. Digital media. Boulder, Colorado.

Pearce, J. M., and K. S. Bollinger. 2003. Morphological characteristics of Pacific Canada Geese to aid identifica- tion and management. Journal of Field Ornithology 74: 357-369.

Quinn, J. L., J. Prop, Y. Kokorev, and J. M. Black. 2003. Predator protection or similar habitat selection in Redbreasted Goose nesting associations: extremes along a continuum. Animal Behavior 65: 297-307.

Raveling, D. G. 1978. The timing of egg laying by northern geese. Auk 95: 294-303.

Reese, K. P., J. A. Kadlec, and L. M. Smith. 1987. Characteristics of islands selected by nesting Canada Geese, Branta canadensis. Canadian Field-Naturalist 101: 539542.

S.A.S. Institute. 1989. SAS/STAT user's guide. Release 6.04 ed. SAS Institute Inc., Cary, North Carolina.

Scribner, K. T., S. L. Talbot, J. M. Pearce, B. J. Pierson, K. S. Bollinger, and D. V. Derksen. 2003. Phylogeography of Canada Geese (Branta canadensis) in western North America. Auk 120: 889-907.

U.S. Fish and Wildlife Service. 2003. Waterfowl population status, 2003. U.S. Department of the Interior, Washington, D.C. 53 pages.

Walter, S.E., and D. H. Rusch. 1997. Accuracy of egg flotation in determining age of Canada Goose nests. Wildlife Society Bulletin 25: 854-857.

Weller, M. W. 1956. A simple field candler for waterfowl eggs. Journal of Wildlife Management 20: 111-113.

Westerskov, K. 1950. Methods for determining the age of game bird eggs. Journal of Wildlife Management 14: 5667.

Received 28 April 2006

Accepted 5 September 2008 